p-ISSN: 2088-6991

e-ISSN: $2548-8376$

Juni 2019
Jurnal Tarbiyah: Jurnal Ilmiah Kependidikan

Vol. 8 No. 1. Januari - Juni 2019 (13-27)

\title{
GLOBALISASI SEBAGAI PROSES SOSIAL DALAM TEOR-TEORI SOSIAL
}

\author{
Laila Azkia \\ Program Studi Pendidikan Sosiologi Antropologi, Fakultas Keguruan dan Ilmu Pendidikan \\ (FKIP), \\ Universitas Lambung Mangkurat (ULM) \\ Email: laila_azkia@yahoo.com/laila.azkia@ac.id \\ Received: Desember 2018; Accepted: Juni 2019; Published: Juni 2019
}

\begin{abstract}
This writing raised the concept of globalization within the framework of the social process. There are four figures where i started, namely Anthony Giddens, John Urry, George Ritzer and Anna Tsing . How giddens express about globalization are reshuffled human life. How Ritzer express about term interestingly the globalization of nothing. And how John Urry with the global complexity-nya see phenomenon globalization as phenomenon complex. Last, choose thought globalization are logically different than most the theory social about globalization, namely thought Anna Tsing in friction-nya. This writing be footing theoretical to research pertaining to to the globalization in indonesia. So that direction and purpose from a written note it is actually is to find being based on theory which is proper for research of globalization on the sacred printing localized in indonesia. The writing them in the way of the interests of to find being based on theory rates ranged from to basis the right method to see the creation of globalization on the sacred printing of foreign currency bank deposits, pt pgn promised to supply look at the process in the form of the interconnectedness of it all social flooding due to local one it with a local another so as to form any of its tissues or the impact of the global connection to the world .
\end{abstract}

Keywords: Globalization; Social Process; Social Theory

\section{ABSTRAK}

Tulisan ini mengangkat konsep globalisasi dalam kerangka proses sosial. Ada empat tokoh yang saya pilih, yaitu Anthony Giddens, John Urry, George Ritzer dan Anna Tsing. Bagaimana Giddens mengungkapkan tentang globalisasi yang merombak kehidupan manusia. Bagaimana Ritzer mengungkapkan tentang term menariknya yaitu Globalization Of Nothing. Serta bagaimana John Urry dengan Global Complexity-nya melihat fenomena globalisasi sebagai fenomena yang kompleks. Terakhir, memilih pemikiran globalisasi yang logikanya berbeda dari kebanyakan teori sosial tentang globalisasi, yaitu pemikiran Anna Tsing dalam Friction-nya. Tulisan ini menjadi pijakan teoritis untuk research yang berkenaan dengan fenomena globalisasi di Indonesia. Sehingga arah dan tujuan tulisan ini sebenarnya adalah menemukan teoritis yang tepat untuk penelitian globalisasi pada ranah lokal di Indonesia. Tulisan ini berada dalam lingkup kepentingan untuk menemukan basis teoritis yang tepat dalam melihat fenomena globalisasi pada ranah lokal, yaitu melihat proses sosial berupa keterhubungan lokal yang satu dengan lokal yang lain sehingga membentuk jaringan atau koneksi global.

Kata Kunci : Globalisasi; Proses Sosial; Teori Sosial

\section{PENDAHULUAN}

Perkembangan ilmu sosial di abad XX begitu pesat. Perkembangan tersebut mengikuti peradaban masyarakat. Masyarakat sedang mengalami apa yang disebut sebagai globalization. Dalam ranah ilmu sosial, begitu banyak teori yang berbicara tentang globalisasi dan perwujudannya. Teori-teori tersebut membahas globalisasi dari berbagai aspek dan dimensi. Kebanyakan teori membahas globalisasi dengan logika atas ke bawah. 
Melihat globalisasi dari sisi besar yang berpengaruh ke hal-hal kecil. Bahwa globalisasi adalah jaringan global ke lokal.

Kebanyakan teoritis terdahulu melihat globalisasi sebagai sesuatu yang tidak berbeda dengan modernisasi bahkan westrnisasi. Hal ini dikarenakan modernisasi adalah sesuatu yang dianggap berasa dari barat khususnya Amerika. Sedangkan modernisasi adalah bagian yang tak terpisahkan dari globalisasi .

Tulisan ini membahas beberapa teori sosial tentang globalisasi. Ada empat tokoh yang saya pilih, yaitu Anthony Giddens, John Urry, George Ritzer dan Anna Tsing. Bagaimana Giddens mengungkapkan tentang globalisasi yang merombak kehidupan manusia. Bagaimana Ritzer mengungkapkan tentang term menariknya yaitu Globalization of Nothing. Serta bagaimana John Urry dengan Global Complexity-nya melihat fenomena globalisasi sebagai fenomena yang kompleks. Terakhir, memilih pemikiran globalisasi yang logikanya berbeda dari kebanyakan teori sosial tentang globalisasi, yaitu pemikiran Anna Tsing dalam Friction-nya. Anna Tsing justru melihat globalisasi dari apa yang ada di lokal bukan di global. Dia justru melihat globalisasi dari dimensi yang partikular bukan universal. Dia tidak sekedar melihat aktor-aktor global yang menyebarkan globalisasi ke lokal, tapi melihat aktoraktor lokal yang turut serta dalam proyek global. Pertanyaan penelitian dalam riset ini adalah (1) Bagaimana Teori-teori Sosial mengungkapkan proses sosial dari Globalisasi ? (2) Bagaimana analisis komparatif teori-teori sosial tersebut?

\section{METODE}

Tulisan ini bertujuan untuk mengkaji teori sosial yang membahas globalisasi. Penulis membandingkan bagaimana Anthony Giddens, George Ritzer, John Urry dan Anna Tsing memaparkan tentang fenomena globalisasi sebagai fenomena sosial yang menarik dewasa ini. Tulisan ini berusaha melakukan analisis komparatif teori-teori tersebut. Metode penelitian dalam tulisan ini adalah secondary data analysis methods, atau metode analisis data sekunder. Data sekunder yang penulis gunakan adalah karya-karya teori sosial tentang globalisasi.

\section{Kerangka Teori / Konsep}

Tulisan dibawah ini memaparkan tentang bagaimana Globalisasi sebagai sebuah fenomena sosial di interpretasikan oleh para ahli ilmu sosial. Paparan pertama dari seorang Sosiolog Eropa yaitu Anthony Giddens yang memaparkan tentang globalisasi sebagai proses yang telah mengubah dunia. Giddens saya pilih menjadi tokoh awal yang bercerita tentang globalisasi pada tulisan ini dikarenakan besarnya efek tulisan Giddens dibelahan dunia. Pemikiran Giddens telah diterjemahkan ke berbagai bahasa di dunia dan telah dibaca oleh jutaan manusia didunia. Pihak yang membaca karya Giddens dan mencermatinya bukan hanya yang bergerak di kajian sosiologi, tetapi juga politik, antropologi, ekonomi, kebijakan publik serta kajian ilmu lainnya. Pemikiran Giddens juga-lah yang menjadi arahan perekonomian dan perpolitikan di Inggris mengingat Giddens adalah penasehat dari Tony Blair, perdana menteri Inggris.

Paparan selanjutnya adalah George Ritzer dengan Globalization of Nothingnya. Ritzer melihat globalisasi sebagai proses penyebaran kehampaan. Kalau Ronald Robertson mengemukakan istilah glokalisasi, maka Ritzer mengemukakan istilah lain yang dianggapnya sebagai rekan dari istilah glokalisasi yaitu grobalisasi. Grobalisasi berasal dari kata grow yaitu pertumbuhan. Gagasan Ritzer kalau dibaca dengan cermat tidak sekedar bicara tentang konsumsi yang dilakukan pada era globalisasi, lebih dari sekedar itu. Ritzer melihat fenomena globalisasi dan grobalisasi sebagai fenomena yang tidak hanya membawa perubahan dalam bidang ekonomi, dalam wujud kapitalisme global, tetapi juga sosial dan budaya. Dimana salah satu aspek globalisasi yaitu 
McDonaldisasi menjelma bukan sekedar sebagai life style tapi ideologi.

Selanjutnya adalah pemikiran Globalisasi dari John Urry dengan Global Complexity-nya. John Urry adalah seorang Sosiologi dari Universitas Lancester, dia menyebutkan bahwa selama ini globalisasi belum memiliki teoritis yang jelas, dikarenakan globalisasi sering dijelaskan sebagai sebuah sebab dan akibat. John Urry saya pilih untuk dipaparkan dalam tulisan ini dikarenakan pemikiran kompleksitasnya menarik untuk dibahas. Logika Urry dalam melihat fenomena sosial dari globalisasi sebagai sebuah kompleksitas berbeda dari bagaimana Giddens dan Ritzer memaparkan dimensidimensi globalisasi yang cenderung ke arah global.

Terakhir adalah paparan dari seorang antropolog, Anna Tsing yang melakukan field research-nya di Asia khususnya Indonesia dan lebih khusus lagi di Pegunungan Meratus, Kalimantan Selatan. Globalisasi dari sudut pandang seorang antropolog relatif berbeda dari globalisasi dari pandangan sosiolog. Globalisasi dalam pandangan antropolog dilihat sebagai sesuatu yang bercorak lokal. Oleh karena itu, gagasan Tsing menarik untuk dibahas. Bagaimana globalisasi dari kacamata lokal. Bukan bagaimana lokal memahami globalisasi, tapi bagaimana lokal berperan dalam proses sosial yang disebut dengan globalisasi.

\section{PEMBAHASAN}

\section{Teori Sosial Tentang Globalisasi}

A. Paparan Giddens berkenaan dengan Globalisasi dan Perwujudannya

Anthony Giddens seorang Profesor Sosiologi dan Universitas Cambridge begitu mengemuka dalam beberapa tahun terakhir. Tulisan-tulisannya dibaca oleh ribuan manusia dibelahan dunia. Pemikirannya tentang demokrasi dan globalisasi dipelajari oleh banyak pihak dengan berbagai macam kepentingan. Buku-bukunya seperti Jalan Ketiga,
Konsekuensi Modernitas dan lain sebagainya telah di terjemahkan kedalam berbagai bahasa. Sehingga tulisan dalam paper ini yang mana mengambil tema tentang globalisasi, patut kiranya untuk mengemukakan terlebih dahulu pemikiran Giddens terutama yang berkaitan dengan globalisasi, sebelum lebih jauh mengungkapkan apa yang menurut penulis tepat dalam menjawab gejala yang akan ditangkap untuk research nanti.

Dalam buku KonsekuensiKonsekuensi Modernitas, sebelum menyajikan pemikirannya tentang globalisasi, Giddens mengungapkan tentang modernitas. Modernitas baginya lebih dari sekedar suatu masa yang dibatasi oleh ruang dan waktu. Modernitas tidak dibatasi dan tidak membatasi ruang dan waktu. Menurut Giddens, modernitas adalah bentuk kehidupan sosial atau organisasi yang muncul di Eropa kira-kira abad ke-17 dan sesudahnya dan yang pada gilirannya menancapkan pengaruhnya ke seluruh dunia (2005:1). Konsepsi tentang modernitas dalam dimensi ruang dan waktu inilah yang mempengaruhi pemikirannya tentang fenomena globalisasi.

Menurut Giddens (2001:xxi), globalisasi merombak cara hidup manusia secara besar-besaran. Dimana globalisasi tersebut berasal dari barat, yang membawa jejak kuat kekuasaan politik dan ekonomi Amerika, serta mempunyai konsekuensi yang sangat tidak seimbang. Namun, globalisasi bukan sekedar soal dominasi Barat terhadap yang lain, globalisasi juga mempengaruhi Amerika Serikat sebagaimana negara-negara lain. Serta globalisasi juga mempengaruhi kehidupan sehari-hari dengan kadar yang sama dengan pengaruhnya terhadap berbagai peristiwa di tingkat dunia.

Globalisasi memiliki dimensi ekonomi, politik, teknologi dan budaya. Lebih lanjut Giddens mengungkapkan bahwa globalisasi terutama sekali dipengaruhi oleh perkembangan sistem komunikasi yang dimulai akhir tahun 
1960-an. Giddens mengemukakan bahwa globalisasi bukan sekedar soal apa yang ada "di luar sana", terpisah, dan jauh dari orang per orang. Ia juga merupakan fenomena "di sini", yang mempengaruhi aspek-aspek kehidupan kita yang intim dan pribadi (2003:7). Menurut Giddens kerangka konseptual pertentangan wakturuang mengarahkan pada hubunganhubungan yang kompleks antara peristiwa lokal dan interaksi lintas jarak. Dalam kondisi modern, tingkat pertentangan waktu-ruang jauh lebih tinggi dibanding kurun sebelumnya, dan hubungan antara peristiwa lokal dan yang jauh direntang. Globalisasi terutama mengacu pada proses perentangan ini (2005:64). Sehingga globalisasi merupakan serangkaian proses yang kompleks, bukan sebuah proses tunggal yang hanya melibatkan satu dimensi saja .

Teoritis ilmu sosial menurut Giddens (2003:8) kebanyakan hanya melihat fenomena globalisasi sebagai pengaruh dan daya yang bergerak meninggalkan bangsa serta meninggalkan komunitas lokal memasuki arena global. Globalisasi tidak hanya membuat bangsabangsa kehilangan sebagian kekuatan ekonominya, Tetapi, globalisasi juga mendorong kebawah yang artinya globalisasi membuat tekanan-tekanan baru bagi otonomi lokal. Selain menarik keatas dan mendorong kebawah, globalisasi juga menekan ke samping. Dimana globalisasi membuat zona-zona ekonomi dan budaya baru di dalam dan antar bangsa.

Globalisasi bukan hanya, atau bahkan terutama, tentang saling ketergantungan ekonomi, tetapi tentang transformasi waktu dan ruang dalam kehidupan kita. Peristiwa di tempat yang jauh, entah yang berkaitan dengan ekonomi atau tidak, mempengaruhi kita secara lebih langsung dan segera daripada yang pernah terjadi sebelumnya. Sebaliknya, keputusan yang kita ambil sebagai individu-individu sering kali memiliki implikasi global (2002:35). Globalisasi melibatkan pasar kapitalis dan seperangkat relasi sosial dan aliran komoditas, kapital, teknologi, ide-ide, bentuk-bentuk kultur, dan penduduk yang melewati batas-batas nasional via jaringan masyarakat global (Ritzer, 2003:590)

Peradaban memiliki masa muda, matang, tua dan ketika mereka digantikan oleh peradaban lain, distribusi regional kekuasaan global mengalami pergeseran. Melemahnya cengkraman Barat terhadap seluruh dunia bukan merupakan akibat dari dampak kemunduran institusi yang pertama kali muncul di sana, namun sebaliknya, merupakan akibat dari persebaran global yang terjadi. (2005:68) Kapitalisme adalah sistem produksi komoditas, yang terpusat pada relasi antara kepemilikan modal pribadi dan pekerja upahan yang tidak menguasai hak milik, relasi ini membentuk poros utama sistem kelas (2005:74). Kapitalisme secara inheren sangat dinamis karena adanya kaitan yang terjalin antara perusahaan ekonomi yang kompetitif dengan proses komodifikasi yang digeneralisasi. (2005:80) Globalisasi pada dasarnya mengacu kepada proses pembesaran, sejauh bentuk hubungan antara berbagai konteks atau wilayah sosial membentuk jaringan diseluruh permukaan bumi secara keseluruhan. Globalisasi dapat didefinisikan sebagai intensifikasi relasi sosial sedunia yang menghubungkan lokalitas yang saling berjauhan sedemikian rupa sehingga sejumlah peristiwa sosial dibentuk oleh peristiwa yang terjadi pada jarak bermil-mil dan begitu pula sebaliknya. (2005:84) Globalisasi telah membuat di negara-negara Barat baik itu lembaga publik maupun kehidupan seharihari semakin terlepas dari cengkraman tradisi. Sedangkan masyarakat lain diseluruh dunia yang memang masih tradisional semakin mengalami detradisionalisasi (2003:40).

Dimensi globalisasi menurut Giddens adalah Dimensi pertama yaitu ekonomi kapitalis dunia, yaitu jaringan mata rantai ekonomi yang tertata dalam cakupan geografis yang cukup luas. Kapitalisme hadir dengan skala cakupan 
global dan lebih banyak didasarkan kepada kekuatan ekonomi daripada kekuasaan politik. Ekonomi kapitalis dunia, terintegrasi melalui hubungan niaga dan manufaktur, bukan melalui pusat politik, yaitu negara bangsa. Giddens (2005:90) mengutip pemikiran Wallerstein untuk menjelaskan global kapitalisme, menurutnya kapitalisme sedari awal adalah urusan ekonomi dunia dan bukan negara bangsa, modal tidak pernah membiarkan aspirasinya ditentukan oleh batas-batas nasional. Lebih lanjut, Giddens mengungkapkan bahwa kapitalisme memiliki pengaruh global yang sedemikian fundamental karena ia lebih merupakan tatanan ekonomi ketimbang tatanan politik. Kapitalisme mampu melakukan penetrasi begitu jauh ke seluruh wilayah yang asal-usulnya tidak mungkin dikendalikan oleh kekuasaan politik.

Dimensi kedua yaitu sistem negara bangsa, dimana pusat-pusat utama kekuasaan dalam ekonomi dunia adalah negara-negara kapitalis, negara dimana perusahaan ekonomi kapitalis menjadi bentuk utama produksi. Negara bangsa merupakan aktor utama di dalam tatanan politik global dan korporasi adalah agen dominan didalamnya. Menurut Giddens (2005:95-96), salah satu aspek dari sifat dialektis globalisasi adalah dorongan dan tarikan antara sejumlah kecenderungan ke arah sentralisasi yang melekat di dalam refleksivitas sistem negara pada satu sisi dan kedaulatan negara tertentu pada sisi lain.

Dimensi ketiga dari globalisasi adalah tatanan militer dunia. Menurut Giddens, dalam persoalan persenjataan tidak ada istilah negara dunia ketiga, yang ada hanyalah negara dunia pertama, dikarenakan hampir semua negara memiliki persenjataan berteknologi canggih. Persenjataan tidak hanya terkait dengan angakatn bersenjata masingmasing negara, tetapi juga perang. Perang yang terjadi terutama perang dunia 1 dan 2, membuktikan bahwa konflik lokal bisa terseret kearah keterlibatan global.
Terakhir, yaitu dimensi keempat globalisasi yaitu pembagian kerja internasional. Dimana terjadi diferensiasi antar kawasan industri di dunia ini. Dalam industri modern, ada pembagian kerja pada spesialisasi regional dalam hal jenis industri, keterampilan, dan produksi bahan mentah. Namun, kebutuhan global yang semakin besar membuat diferensiasi tersebut berubah, distribusi global berubah termasuk deindustrialisasi beberapa kawasan dinegara-negara berkembang dan munculah negara-negara industri baru.

Giddens memusatkan pikirannya pada bagaimana globalisasi telah merubah dunia. Dia menyiratkan globalisasi sebagai sesuatu yang datang dan merubah tempat yang didatanginya. Bagaimana globalisasi tersebut telah mendorong ke bawah, menekan ke samping dan menarik keatas, merupakan pemikiran Giddens yang mengandung makna bahwa globalisasi adalah sesuatu yang datang dan adalah entitas yang terpisah dari yang didatangi. Globalisasi berasal dari barat namun ia juga mempengaruhi barat. Pemikiran Giddens tersebut merupakan pemikiran yang menekankan bahwa globalisasi adalah sesuatu yang berasal dari sebuah tempat dan datang ketempat lain serta memperngaruhi tempat lain dan tempat asalnya tersebut. Pemikiran Giddens yang seperti itu tidak sepadan dengan apa yang dipikirkan tokoh sosial lain yang juga mengkritisi fenomena globalisasi, salah satunya adalah James Petras.

James Petras dalam Globalization:

A Critical Analysis-nya mengungkapkan tentang siapa saja pihak-pihak yang merupakan aktor dalam globalisasi. Aktor globalisasi baginya bukan hanya orang Barat yang membawa globalisasi ke penjuru dunia, namun aktor globalisasi ada tiga pihak, yaitu (1) Pihak yang mendukung globalisasi, yaitu mereka yang memperoleh keuntungan dari adanya globalisasi, (2) Pihak yang menentang globalisasi, yaitu mereka yang menjadi korban eksploitasi, dan (3) Pihak yang dieksploitasi namun juga memperoleh 
keuntungan dari globalisasi, oleh karena itu pihak tersebut ragu dalam memberi respon terhadap globalisasi. Bagi Petras aktor-aktor itulah yang terlibat dalam globalisasi, sehingga globalisasi bukan sekedar sesuatu hal yang datang. Ada pihak ketiga, yaitu pihak yang dieksplotasi namun juga memperoleh untung menyiratkan bahwa dalam globalisasi ada peran aktif berbagai pihak, bukan sekedar peran aktif pihak yang mendukung globalisasi namun juga peran aktif pihak yang ragu terhadap globalisasi. Globalisasi adalah proses yang dilakukan secara aktif bukan hanya oleh negara maju, namun negara dunia ketiga atau negara berkembang pun ikut berperan dan memberikan kontribusinya pada proses globalisasi tersebut.

Detradisionalisasi adalah point penting bagi Giddens untuk menjelaskan fenomena globalisasi. Dimana menurutnya masyarakat tradisional di belahan dunia mengalaminya, yaitu proses semakin memudarnya tradisi-tradisi lokal, tradisi yang ada dilokal mulai ditinggalkan masyarakat lokal. Globalisasi adalah penyebab dari detradisionalisasi. Masyarakat menjadi satu, sama dan mengikuti global, keragaman memudar dan berproses menuju homogenitas. Pemikiran semacam ini dikritik Ronald Robertson, menurutnya apa ia globalisasi membuat orang menjadi semakin homogen? Tidak kah globalisasi membuat orang juga menjadi semakin heterogen? Karena heterogen itu justru menjual dalam era globalisasi. Oleh karena itu hadirlah istilah glokalisasi dari Robertson yang intinya adalah mengungkapkan bahwa lokal dan global tetap ada.

\section{B. Globalisasi Dalam Pandangan George Ritzer}

Ritzer dalam Globalization of Nothing-nya mengungkapkan bahwa globalisasi memiliki kecenderungan menyebarkan nothing ke seluruh dunia. Yang dimaksud nothing oleh Ritzer (2006:3) adalah sebuah bentuk sosial yang umumnya disusun, dikontrol secara terpusat, dan termasuk tanpa isi substanstif yang berbeda. Dimana definisi nothing tersebut menunjukkan tidak adanya keputusan tentang yang diinginkan atau tidak diinginkan dari bentuk sosial tersebut.

Globalisasi menurut Ritzer adalah penyebaran kebiasaan-kebiasaan yang mendunia, ekspansi hubungan yang melintasi benua, organisasi dari kehidupan sosial pada skala global dan pertumbuhan dari sebuah kesadaran global bersama (2006:96). Tesis utama yang ingin dijawab Ritzer dalam Globalization of Nothing-nya adalah "Apakah perubahan global menyebabkan homogenitas yang semakin meningkat atau heterogenitas yang semakin meningkat atau sebuah campuran dari keduanya?" serta "Apa hubungan antara lokal dengan global?". Tesis tersebut sebenarnya mengutip pemikiran Ronald Robertson dalam teori globalisasi. Kalau Robertson mengeluarkan konsep glokalisasi, maka Ritzer hadir dengan konsep grobalisasi.

Glokalisasi

merupakan interpenetrasi global dan lokal yang memberikan hasil unik dalam wilayah geografis yang berbeda. Bagi Ritzer, grobalisasi adalah konsep rekan dari glokalisasi yang fokus pada ambisi-ambisi imperialistik dari negara-negara, perusahaan-perusahaan, organisasiorganisasi dan kesukaan serta keinginan mereka untuk menempatkan diri mereka sendiri pada berbagai wilayah geografis. Perhatian utamanya adalah pada kekuatan pengaruh serta pertumbuhan keuntungan dalam perekonomian diseluruh dunia. Lebih lanjut Ritzer mengemukakan bahwa grobalisasi melibatkan berbagai macam subproses, tiga diantaranya yaitu kapitalisme, Amerikanisasi, dan McDonaldisasi.

Kapitalisme adalah kekuatan yang memberikan kontribusi yang besar terhadap perkembangan globalisasi. Bisnis-bisnis kapitalistik selalu memiliki ambisi global, tertarik pada grobalisasi dan memberikan kontribusi kepada glokalisasi. 
Subproses yang kedua yaitu Amerikanisasi yang merupakan perkembangan ide-ide, kekuasaan, pola-pola sosial, industri dan modal Amerika ke seluruh dunia. Amerikanisasi masuk menjadi subproses globalisasi menurut Ritzer karena Amerikanisasi memimpikan sebuah pertumbuhan dalam pengaruh Amerika pada semua bidang diseluruh dunia. Subproses selanjutnya adalah McDonaldisasi merupakan proses sosial yang menerapkan prinsip-prinsip restoran cepat saji, yaitu efisiensi, kemampuan menghitung, kemampuan memprediksi, dan mengontrol. McDonaldisasi tidak memiliki batas yang sama dengan globalisasi juga bukan sekedar proses global. Namun, McDonaldisasi memiliki implikasi-implikasi global dan merupakan sebuah lensa yang berguna untuk mengamati perubahan-perubahan yang terjadi diseluruh dunia.

Heru Nugroho (2006:xxix) dalam Pengantar "Mengkonsumsi Kehampaan di Era Global" menyebutkan bahwa Ritzer melihat fenomena glokalisasi merupakan interaksi global dan lokal yang menghasilkan sesuatu yang baru, yaitu glokal. Sedangkan grobalisasi adalah istilah yang diciptakan Ritzer untuk memparalelkan gagasan glokalisasi. Grobalisasi digunakan untuk mengambarkan proses dalam mana perintah-perintah pertumbuhan mendorong berbagai organisasi untuk melakukan ekspansi secara global dan untuk membebankan diri mereka sendiri atas halhal lokal. Ritzer melihat globalisasi sebagai perlibatan dua sub-proses utama, yang mana keduanya adalah global dan masing-masingnya terlibat dalam perselisihan besar antar satu dengan yang lain. Ritzer menegaskan bahwa globalisasi melibatkan sebuah perjuangan mendalam antara grobal dan glokal.

Ritzer mengamati lebih jauh tentang fenomena McDonalisasi yang menurutnya adalah salah satu subproses dari globalisasi. Dimana subproses lainnya yaitu kapitalisme dan westernisasi. Ia juga mengeluarkan sebuah konsep baru yaitu grobalisasi yang adalah rekan dari konsep globalisasi. Analisisnya adalah bahwa grobalisasi membuat dunia tumbuh menjadi semakin serupa. Analisis ini sesuai dengan apa yang juga dianalisis oleh tokoh teori sosial Modern lain yang mengemukakan tentang ke-universalan pada era modern. Era modern ditandai dengan keseragaman atau keuniversalan terutama dalam pakaian, makanan, pengetahuan dan lain sebagainya. Inilah satu titik pijakan Ritzer saat bicara tentang globalisasi dan grobalisasi.

\section{Globalisasi Dalam Pandangan John Urry}

John Urry adalah seorang sosiolog dari Universitas Lancaster yang telah mendirikan Pusat Mobilitas Penelitian pada program Sosiologi di Universitasnya. Ia banyak mengkaji dan menulis dalam bidang perubahan sosial, posmodernitas, kapitalisme, pariwisata, serta yang akan dibahas dalam tulisan ini yaitu globalisasi dalam lingkup Global Complexity. Ia memiliki ketertarikan mencermati fenomena globalisasi dikarenakan menurutnya selama ini globalisasi baik dalam kajian ilmu sosial maupun kajian lain belum diteorisasikan secara memadai. Selama ini, konsep globalisasi kebanyakan dipergunakan dengan perannya sebagai sebab dan akibat. Oleh karena itu, menurut Urry perlu dicermati apakah kajian kompleksitas ilmu dapat memberikan konsep dan metode yang memperjelas posisi globalisasi dalam perkembangannya.

Dalam Global Complexity, Urry membuka tulisannya dengan menanggapi teori strukturasi Anthony Giddens. Menurutnya Giddens telah memberi pemikiran baru atas kebuntuan teoritis sosial yang sangat mempersoalkan peran struktur dan agen. Lewat dualitas struktur, Giddens memaparkan bahwa semua tindakan sosial manusia berada dalam konteks struktur dan semua tindakan tersebut tercakup dalam struktur. Inti dari dualitas struktur Giddens adalah bahwa 
hubungan antara struktur dan tindakan bukanlah dua sisi yang terpisah dari satu gejala sosial atau dualisme, melainkan mencerminkan dualitas yang artinya sifatsifat atau ciri-ciri struktural dari sistem sosial adalah sarana sekaligus hasil dari praktek sosial yang terus menerus terjadi. Namun, menurut Urry, Giddens kurang meneliti komplek dan sistemik karakter dari proses struktur dan agen. Dalam tulisannya yang lain yaitu The Complexities of the Globe, Urry juga mengutip pandangan Giddens tentang "juggernaut" atau raksasa besar. Dunia modern menurut Giddens seperti layaknya pengemudi yang keluar dari sistem kontrol raksasa yang telah ditetapkan dalam proses yang takterbalikkan yang membentang diseluruh dunia dan menghasilkan efek samping yang tak terkendali. Gagasangagasan Giddens seperti diatas-lah yang menjadi salah satu inspirasi Urry dalam pemikirannya tentang global complexity. Urry (2005:336) menyebarkan gagasan global complexity untuk meneliti peristiwa-peristiwa yang terjadi secara tidak merata, tidak terduga dan untuk waktu yang tidak dapat diulang dari perubahan besar diseluruh landskap kontemporer.

Urry mengamati bagaimana pemikiran-pemikiran yang cenderung mengandung kekacauan dan kompleksitas dapat membantu dalam menganalisas proses global. Menurutnya ide kompleksitas menekankan bahwa sistem yang seimbang selalu bergerak antara keteraturan dan kekacauan. Dimana sistem tidak selalu bergerak ke arah equiliribrium atau keteraturan semata dan bahwa terdapat peristiwa-peristiwa yang tak terduga dan keduanya irresersible dalam efeknya. Kompleksitas menjelaskan bagaimana ketertiban dan gangguan ada dalam berbagai sistem global. Dimana tatanan global adalah dunia yang kompleks, tidak terduga dan tidak dapat berubah, kacau namun tidak anarkis.

Urry berargumen bahwa global complexity adalah sebuah sistem yang memiliki dua bentuk yaitu global network atau jaringan global dan global fluids atau cairan global. Jaringan global menurut Urry seperti layaknya McDonald's dengan suatu jaringan erat yang bersifat kompleks, abadi dan dapat diprediksi hubungan antara masyarakat, objek dan teknologi yang terdiri di beberapa dan berjarak ruang dan waktu. Didalam jaringan global terdapat jarak relatif, yaitu fungsi dari hubungan antara komponen-komponen yang terdapat dalam jaringan tersebut. Jarak relatif dalam jaringan global membuat hubungan antar jaringan dekat sehingga mengatasi masalah-masalah batas daerah. Sebagaimana jaringan teknologi, keterampilan, teks dan merk, global hybrid memastikan bahwa layanan dan produk yang sama diantarkan melalui lebih atau kurang beberapa jalan dari jaringan yang ada. Produk tersebut telah diprediksi, dihitung, dirutinkan dan distandarkan. Ada banyak perusahaan global yang bekerja melalui sistem jaringan seperti itu, sebut saja McDonald, American Express, Coco Cola, dan lain sebagainya.

Sedangkan global fluids atau cairan global, seperti uang, internet, gerakan sosial, terorisme internasional, perjalanan orang-orang, penggalian informasi, dan lain sebagainya. Cairan global bergerak disepanjang jenis lanskap, dan memiliki kemungkinan untuk melarikan diri. Urry menganalogikan cairan global seperti sel darah putih, yang bergerak sesuai dengan bentuk yang ada dari materi yang dilewatinya dan memiliki efek konsekuensi yang tidak terduga atas hal tersebut. Sebagaimana cairan, hasil dari aktivitas individu yang berbasis pada informasi lokal tetapi dimana aktivitas lokal berlangsung, melalui interaksi yang tak terhitung jumlahnya, ditangkap, dipindahkan, diwakili, dipasarkan dan umum sering mempengaruhi pada tempat yang sangat jauh serta mempengaruhi masyarakat yang ada.

Kompleksitas global terdiri dari banyak perbedaan dari pulau ketertiban (island order) dan lautan kekacauan (a sea 
of disorder). Di dalam kompleksitas global terdapat jaringan global dan cairan global, ada masyarakat nasional, diaspora, negara supranasional, agama global atau peradaban, organisasi-organisasi internasional, pertemuan internasional, LSM dan lintas batas wilayah. Urry mengutip Habermas, yang mengungkapkan kalau globalisasi memunculkan gambar sungai meluap, membasuh semua pos pemeriksaan perbatasan dan kontrol, dan akhirnya membasuh bangsa itu sendiri.

Jadi, Urry berada dititik kegalauan terhadap studi-studi globalisasi yang menurutnya kehilangan aspek penting. Urry mencoba melihat globalisasi sebagai sebuah kompleksitas global. Yang didalamnya terhadap keseimbangan yang artinya proses yang teratur dan kacau. Didalamnya juga terdapat kekuasaan yang tidak seimbang, cairan dan jaringan. Urry melihat bahwa ide tentang kompleksitas dapat membantu memahami dunia materi yang beragam yang mana berimplikasi pada proses globalisasi baik dari segi ekonomi, sosial, politik, budaya maupun hubungan lingkungan. Urry mengemukakan bahwa globalisasi menjadi konseptualisasi dari sebuah kumpulan adaptasi dan sistem global yang berkembang bersama, yang mana karakteristiknya adalah tidak bisa diprediksi, tidak bisa kembali dan berevolusi bersama.

Ide tentang kompleksitas menjadi bahasan yang cukup menarik beberapa dekade terakhir. John Urry adalah tokoh sentral dalam bahasan kompleksitas tersebut. Buku Global Complexity-nya telah membuka bidang yang sama sekali baru dalam penelitian ilmu sosial. Menurut Urry selama ini ide tentang kompleksitas banyak dimanfaatkan oleh pemikirpemikir modernitas dan globalisasi, walau pemikir tersebut menggunakannya secara eksplisit saja.

\section{Konsepsi Tsing tentang Globalisasi}

Anna Lowenhaupt Tsing seorang Antropolog dari Universitas California pada tahun 1994 mendapat penghargaan Benda Prize yaitu penghargaan dari asosiasi ilmuwan Amerika dengan spesialisasi Asia. Ia melakukan penelitian di beberapa negara Asia, salah satunya Indonesia. Di Indonesia, penelitian Tsing fokus di lokasi Pegunungan Meratus Kalimantan Selatan. Ada beberapa jurnal yang ditulis Tsing tentang hasil penelitiannya tersebut dan setidaknya dua buku yaitu In the Realm of the Diamond Queen yang telah diterjemahkan ke dalam bahasa Indonesia dengan judul "Di bawah Bayang-Bayang Ratu Intan" dan "Friction An Ethnography of Global Connection". Buku Friction sekarang ini menjadi buku wajib untuk mahasiswa antropologi di beberapa universitas di Eropa. Buku tersebut setidaknya telah memberikan angin segar bagi para antropolog, mengingat selama ini beberapa Antropolog merasa tidak memiliki landscape yang jelas dalam studi-studi globalisasi yang berkembang pesat dalam beberapa tahun terakhir. Tsing lewat buku tersebut, mengemukakan sebuah logika terbalik dari logika-logika yang ada selama ini tentang globalisasi. Logika terbalik inilah yang telah membuka pintu masuknya antropolog-antropolog kedalam studi tentang globalisasi.

Tsing dalam Introduce buku Friction mengemukakan "Global connections are everywhere. So how does one study the global?". Melalui Friction, Tsing mencoba memaparkan sisi mana atau logika seperti apa yang bisa menjadi landscape penelitian. Tsing mengemukakan tentang global connection yang dilihatnya dengan logika terbalik, dimana ia mampu menarik konsepsikonsepsi lokal yang ditemukannya didaerah atau dilokasi penelitiannya ke dalam konsep global yaitu globalisasi. Kalau kebanyakan ilmuwan sosial melihat globalisasi dari atas, atau dari sisi globalnya, maka Tsing berbeda. Tsing justru melihat bagaimana globalisasi itu bekerja dalam ranah lokal dan bagaimana lokal 
tersebut disadari atau pun tidak telah aktif dalam proyek globalisasi.

Tsing mengemukakan tentang koneksi global yang menurutnya adalah alat dalam mencapai atau menuju universal. Kapitalisme, pengetahuan dan politik semua tergantung pada koneksi global. Koneksi global-lah yang mewujudkan mimpi universal. Dimana universal menurut Tsing sudah masuk dalam budaya yang sangat kontekstual dan khas. Ada dua kalimat inti dari pemikiran Tsing tentang universal yaitu "universal claims do not actually make everything everywhere the same" dan "universal work out in particular times and places". Namun apa bukti dari adanya koneksi global? Tsing mengemukakan bahwa bukti dari adanya koneksi global adalah hutan yang ada di Indonesia tidak lah rusak untuk memenuhi kebutuhan lokal masyarakat Indonesia, tetapi hasil hutan diambil untuk kebutuhan masyarakat dunia.

Jaringan panjang dari lokal ke global masuk melalui perdagangan, kekuasaan dan pemaknaan. Dimana budaya manusia terbentuk dan tertransformasikan dalam sejarah panjang dari daerah atau regional ke jaringan global. Bagaimana budaya manusia bisa tertransformasikan ke jaringan global? jawabanya adalah karena universalitas yang ada tidak lagi bersifat grand narasi. universalitas tidak hanya berarti segala sesuatu di segala tempat sama, tetapi universal juga ditemukan dalam hal-hal yang partikular. Karena menurut Tsing, hal-hal yang partikular itu hadir untuk meneguhkan universal. Dimana mimpimimpi universal yaitu kemakmuran, pengetahuan dan kebebasan diwujudkan oleh partikular. Lebih lanjut menurut Tsing, universal dan partikular secara bersama-sama menciptakan bentuk-bentuk kapitalisme.

Bagaimana budaya dan koneksi global terus berlangsung? Friction-lah jawabanya. Budaya terus direproduksi dalam interaksi yang disebut dengan friction. Koneksi global terus terjadi karena adanya friction. Dan friction telah membuat koneksi global semakin kuat dan efektif. Friction atau gesekan, adalah pertemuan antara global dan lokal, yang merupakan bentuk budaya yang terus menerus diproduksi. Gesekan terus dipertahankan untuk memenuhi kepentingan. Kebutuhan global dianggap sebagai kesempatan bagi lokal. Sehingga apapun yang bernilai bisa menjadi komoditas. Maka jawaban dari pertanyaan Tsing dalam buku tersebut terjawab sudah, yaitu bagaimana orang-orang biasa terlibat dalam menghancurkan lingkungannya, bahkan menghancurkan tempat mereka sendiri.

Aktor-aktor dalam gesekan yang terus mempertahankan gesekan karena adanya kepentingan disebut Tsing dengan istilah frontiers. Frontiers terus mempertahankan moment produktif antara hal-hal yang legal dan illegal, hal-hal yang bersifat publik dan yang bersifat privat, dan lainlain. Gesekan tersebut berada dalam ruang yang penuh kepentingan yaitu interstitial spaces. sehingga dapat disimpulkan bahwa friction adalah sebuah proses sosial yang dilakukan oleh frontiers dalam interstitial spaces. Terpenting menurut Tsing bukanlah dikotomi antara individu dan masyarakat, tapi proses diantara keduanya. proses tersebut berada dalam ruang, bukan ruang hampa, melainkan ruang yang penuh dengan kepentingan di dalamnya. The forest is a terrain of personal biography and community history".

Mimpi-mimpi universal yang diwujudkan oleh partikular adalah kesejahteraan, pengetahuan dan kebebasan. Dimana kesejahteraan tersebut dibentuk dalam gesekan. Banyak orang yang menurut Tsing merasa diuntungkan dengan letupan sumber daya, kebutuhankebutuhan yang merupakan ekspansi kapitalis seperti rokok, pembunuh hama, pakaian dan segala sesuatu yang dianggap "modern" masuk dalam ranah-ranah lokal. Sehingga sebenarnya istilah "kesejahteraan" masuk dalam masyarakat 
lokal lewat konstruksi kebutuhankebutuhan (palsu) yang merupakan bentuk ekspansi kapitalis. Sehingga sumber daya (hutan, tambang dan lain-lain) dijadikan komoditas untuk membeli hal yang dianggap sebagai bagian dari "kesejahteraan". Salah satu kalimat menarik yang ditemukan Tsing dalam penelitiannya yaitu "if you don't wreck and rampage, your rice pot will be empty".

Mimpi universal yang kedua adalah knowledge atau pengetahuan. Menurut Tsing, pengetahuan adalah jembatan menuju universalitas. Universalitas adalah jembatan menuju mimpi global. Dimana Tsing mengkritik para natural lovers atau pecinta lingkungan yang hidup dengan gaya cosmopolitan dan merokok. Menurut Tsing konservasi lingkungan dipengaruhi oleh sudut pandang yang dominan. Kebebasan adalah mimpi universal yang ketiga. Dimana setiap manusia pasti memimpikan sebuah kebebasan. Para ilmuwan, pencinta alam, dan orang-orang Non-Goverment Organization (NGO) mengharapkan sebuah kebebasan. Dan menjadi aktor dari proyek global dianggap sebagai jalan menuju kebebasan.

Salah satu pertanyaan dasar yang di kemukakan Tsing dalam field work-nya adalah bagaimana masyarakat lokal bisa menghancurkan lingkungan, tempat mereka sendiri? Pertanyaan tersebut terjawab yaitu bahwa masyarakat lokal atau masyarakat sekitar hutan mengangap bahwa kebutuhan global adalah kesempatan bagi lokal untuk mencapai kesejahteraan. Sehingga apa pun, dalam hal ini hasil alam dan lingkungan di jadikan komoditas. Masyarakat sekitar hutan dan masyarakat sekitar sumber daya alam lainnya selain hutan, seperti tambang dan lainnya mengalami perubahan dalam pola memanfaatkan alam. Alam tidak sekedar dipakai untuk memenuhi kebutuhan hidup sehari-hari, tapi lebih dari itu, alam dijadikan alat untuk mencapai kesejahteraan. Kesejahteraan menurut versi yang ditawarkan media kepada mereka, yaitu kepemilikan akan alat transportasi, alat elektronik, dan lain-lain. Mengenai hal ini, Uma Adang yang adalah informan dari field work Tsing mengungkapkan "If there's money in it, people will do it. If they have one million, they want two million. If they have two million, they want three million. Up to tens of million. They don't stop to think. They just want it to multiply : gold, clothing, anything 'modern', electric motors, motorcycles, motor vehicles. Kalimantan is sick" (2005:47).

Tsing juga mengungkapkan dalam Friction (2001 : XX) bahwa di tebangnya pohon dan rusaknya hutan Kalimantan bukan dikarenakan untuk memenuhi kebutuhan masyarakat lokal, namun untuk memenuhi kebutuhan global yaitu masyarakat di luar Kalimantan dan di luar Indonesia. Kayu dan hasil penebangan hutan serta hasil hutan lainnya di ambil dan menjadi komoditas untuk memenuhi permintaan masyarakat dunia. Tsing dalam studinya di Meratus Kalimantan Selatan juga mengungkapkan perihal global connection. Menurutnya ada koneksi global yang telah menghubungkan hal-hal yang bersifat lokal ke global. Dia menemukan koneksi global ini bukan diperkotaan dengan industri yang pesat, tetapi di pegunungan hutan Meratus Kalimantan Selatan tempat field work-nya. Bukti adanya koneksi global disebutkannya adalah "Indonesian forest were not destroyed for local needs, their product were taken for the world" (2005:2).

Kesejahteraan merajuk pada disposisi kemampuan untuk mengonsumsi suatu atau sejumlah jenis barang atau pun jasa yang merupakan produk konsumsi. Makna dari istilah kesejahteraan semacam ini adalah kesejahteraan yang dikembangkan dan disebarkan serta dikonstruksikan oleh para aktor kapitalis atau produsen yang memproduksi barang atau jasa konsumsi. Makna kesejahteraan tersebut dibuat untuk anggota masyarakat yang menjadi sasaran para kapitalis atau produsen. Kapitalisme yang berasaskan 
mencari keuntungan sebesar-besarnya dengan biaya atau beban seringanringannya, membawa pada produksi masal. Produksi massal merupakan produksi yang mampu meminimkan beban produksi dan menghasilkan produk dengan kuantitas yang besar, sehingga keuntungan dari produksi massal sangat menggiurkan para kapitalis atau produsen. Produksi masal membutuhkan konsumen yang besar. Konsumsi dalam kota atau dalam negeri masih merupakan lingkup kecil untuk pemasaran produksi masal. Oleh karena itu ekspansi produk ke luar daerah khususnya ke luar negeri merupakan hal yang patut dilakukan oleh para kapitalis atau produsen. Negara dunia ketiga merupakan pasar yang potensial untuk menjual produk masal yang dihasilkan.

Selain membutuhkan pasar, asas kapitalisme yang tersebut diatas juga membutuhkan bahan mentah produksi dengan harga yang rendah. Bahan mentah untuk produksi umumnya adalah produkproduk alam atau hasil alam. Hasil alam yang dibutuhkan untuk produksi kebanyakan ada di negara dunia ketiga. Oleh karena itu ekspansi ke banyak daerah di belahan bumi yang di lakukan oleh para kapitalis atau produsen dikarenakan dua alasan pokok yaitu : (1) pasar yang menjanjikan dan (2) bahan mentah yang potensial. Selain dua alasan pokok tersebut ada alasan lain yaitu di negara dunia ketiga menyediakan tenaga kerja dengan jumlah yang besar dan dengan upah yang tergolong rendah. Kapitalisme merambah ke banyak aspek dan ke banyak regional melalui saluran yang sangat terbuka saat ini yaitu globalisasi.

\section{Analisis Komparatif : Globalisasi Sebagai Proses Sosial}

Proses Sosial menjadi pilihan dikarenakan gagasannya relevan dengan fenomena globalisasi. Analisis struktural fungsional hanya akan melihat fenomena globalisasi sebagai fenomena struktural yang memaksa individu. Globalisasi dipandang sebagaimana sifat dari fakta sosial, yaitu memaksa dan berada diluar individu. Kacamata semacam itu menurut saya kurang clear dalam melihat fenomena globalisasi yang tentunya tidak sekedar melibatkan struktur semata. Sedangkan analisis tingkat mikro baik analisis melalui kacamata interaksionisme simbolik maupun fenomenologi, melihat fenomena globalisasi dari sisi aktor yang terlibat aktif. Kacamata seperti ini pun pikir belum mampu memaparkan realitas yang sebenarnya dari fenomena globalisasi. Struktural fungsional cenderung mengabaikan peran aktif agen atau aktor dan analisis tingkat mikro cenderung terlalu menonjolkan peran aktor sehingga kekuatan struktur tidak terlalu diperhatikan. Sedangkan proses sosial, adalah kacamata yang melihat secara luas sebuah fenomena. Melihat bagaimana kekuatan struktur dan bagaimana kekuatan aktor. Proses sosial melihat relasi yang terjadi antara struktur dan aktor.

Selama beberapa dekade teoritis ilmu sosial, sibuk memperdebatkan siapa yang lebih berperan kuat apakah masyarakat sebagai sebuah struktur atau individu sebagai seorang aktor. Berdebatan ini tidak ada habisnya sebagaimana perdebatan siapa yang lebih dahulu ada ayam atau telur. Perdebatan tersebut memperoleh angin segar dengan hadirnya perspektif baru dalam melihat realitas sosial yaitu perspektif proses sosial. Perspektif ini tidak hanya melihat bagaimana struktur memaksa individu tetapi juga melihat bagaiaman individu memiliki kemampuan dalam memilih paksaan struktur dan melihat bagaimana kekuatan inidividu sebagai aktor dalam memperngaruhi dan menciptakan struktur. Perspektif ini hadir dari Giddens dengan teori strukturasi yang terkenal dengan istilah dualitas struktur. Serta Bourdieu dengan habitusnya. Baik Giddens maupun Bourdieu memiliki pemikiran semacam itu dikarenakan terpengaruh oleh pemikiran sosiolog Jerman, yaitu Norbert Elias dengan konsep khasnya yaitu figurasi. 
Konsep figurasi menurut Elias
adalah "memungkinkan menentang tekanan kondisi sosial yang memisahkan dan mempertentangkan konsep kemanusiaan kita, yang telah berulangulang mencegah kita berpikir tentang rakyat sebagai individu dan pada waktu bersamaan memikirkan mereka sebagai sebuah masyarakat.... Konsep figurasi berfungsi sebagai peralatan konseptual untuk melenyapkan keterbatasan sosial ini dalam membicarakan dan memikirkan seolah-olah individu dan masyarakat berbeda dan bertentangan". Figurasi adalah proses sosial yang menyebabkan terbentuknya jalinan hubungan antara individu. Figurasi bukan struktur yang berada diluar individu, yang bersifat memaksa relasi antar individu, figurasi adalah antar hubungan itu sendiri. Individu dipandang sebagai terbuka dan saling tergantung, figurasi tersusun dari kumpulan individu-individu. Dan kekuasaan adalah aspek penting dalam figurasi, dimana sifat dari figurasi tersebut adalah dinamis atau selalu mengalami perubahan. Dalam buku What Is Sociology (dalam Ritzer, 2005:489), Elias mengungkapkan bahwa "inti figurasi sosial yang senantiasa berubah adalah fluktuasi, keseimbangan yang dapat tegang dan kendur, keseimbangan kekuasaan yang berubah, mula-mula kearah satu sisi dan kemudian ke sisi lain. Fluktuasi keseimbangan kekuasaan ini adalah ciri-ciri struktural aliran setiap figurasi sosial."

Konsep figurasi bisa diterapkan pada tingkat mikro maupun makro serta untuk semua fenomena sosial yang berada diantara kedua kutub mikro dan makro tersebut. Konsep figurasi sosial yang diungkapkan oleh Elias (Ritzer 2005:489) : dapat diterapkan baik pada kelompok kecil maupun pada masyarakat yang beranggota ribuan atau jutaan orang yang saling tergantung. Guru dan murid dikelas, dokter dan pasien dalam sebuah kelompok terapi atau klinik, pengunjung biasa disebuah tempat hiburan, anak-anak ditaman kanak-kanak, mereka semuanya dapat dipandang membentuk figurasi satu sama lain. Tetapi, meski dalam contoh ini figurasi itu tak dapat dirasakan secara langsung karena rantai saling ketergantungan yang menghubungkan orang secara bersamaan adalah lebih panjang dan lebih berlainan.

Elias mengungkapkan bahwa harusnya sosiologi bukanlah memusatkan pikirannya pada dikotomi masyarakat dan individu. Tetapi fokus utama sosiologi harusnya adalah "Bagaimana dan mengapa orang mengikatkan diri bersama-sama membentuk figurasi dinamis tertentu adalah salah satu persoalan sentral, bahkan mungkin merupakan pertanyaan sentral itu sendiri dalam sosiologi". Pemikiran Elias tentang figurasi berkaitan dengan pemikirannya bahwa individu adalah terbuka terhadap dan saling berhubungan dengan individu lain. Ia menyatakan bahwa kebanyakan sosiolog beroperasi dengan pemahaman tentang homo clausus, yaitu gambaran bahwa setiap orang akhirnya bebas secara mutlak dari semua orang lainm setiap orang akhirnya bebas secara mutlak dari semua orang lain, setiap orang menjadi individu di dalam dirinya. Gambaran tentang aktor yang terbuka dan saling tergantung diperlukan untuk sosiologi figurasional.

Pemikiran Tsing tentang globalisasi sejalan dengan pemikiran dasar Elias dalam Figurasi. Globalisasi bukan proses dari atas kebawah, bukan proses dari barat ke timur, tetapi sebuah proses jalinan hubungan antar lokal satu dengan lokal lain. Sehingga globalisasi sebagai sebuah proses adalah juga figurasi. Yang artinya sebagaimana sifat figurasi, yaitu terjadi saling keterhubungan dan ketergantungan antar masing-masing elemen begitu pula globalisasi. Globalisasi merupakan proses keterhubungan yang ditunjang lewat ketergantungan bukan hanya ketergantungan lokal pada global (timur dengan barat) tetapi juga 
ketergantungan global pada lokal (barat dengan timur).

Penelitian-penelitian globalisasi

dinegara-negara dunia ketiga membutuhkan dasar teortis yang tepat. Kenapa? agar fenomena globalisasi tersebut terlihat secara jelas dan kompleks. Teoritis yang tepat itu seperti apa? teoritis yang tepat adalah yang memandang globalisasi bukan sekedar proses disisi global tapi melihat keseluruhan prosesnya, yaitu keterhubungan dalam proses tersebut, keterhubungan antar lokal-lokal yang membentuk global. Tsing melakukan logika semacam itu dalam riset-risetnya di negara dunia ketiga. Logika terbalik Tsing menurut hemat cocok untuk melihat fenomena globalisasi di Indonesia pada khusunya.

Tsing dalam bahasannya tentang fenomena globalisasi sebenarnya mencoba mengungkapkan akan adanya peran aktif lokal. Frontier-frontier lokal menunjukkan bahwa aktor-aktor dalam globalisasi bukan hanya orang yang berada dikota atau di pusat tetapi juga adalah mereka-mereka yang ada di lokal. Masyarakat lokal menjadi aktor dalam globalisasi. Masyarakat lokal memiliki kepentingan dalam proses sosial globalisasi begitu juga masyarakat di kota atau di pusat. Kepentingan antar mereka berbeda, namun kepentingan-kepentingan tersebut bukan saling berlawanan melainkan bertemu dalam friksi. Pertemuan kepentingan ini menandakan bahwa aktor lokal maupun aktor global memiliki peran dalam proyek globalisasi.

Kalau ditarik dalam ranah negara berkembang dan negara maju yang mana selama ini selalu dianggap bahwa hanya negara majulah yang mendapat keuntungan dan yang memanfaatkan globalisasi. Hanya negara majulah yang menjadi aktor dari proyek globalisasi. Sedangkan negara berkembang dianggap hanya menjadi korban. Negara berkembang dianggap hanya memiliki peran pasif dan tidak mampu memanfaatkan proses globalisasi yang telah merambah ke berbagai aspek tersebut. Tsing mencoba melihat dari sisi berbeda. Ia melihat di dalam lokal-lokal sendiri terlihat bagaimana peran aktif masyarakat lokal dalam koneksi global. Tsing menemukan dalam research-nya di pedalaman Kalimantan Selatan, bahwa negara berkembang tidak selalu menjadi korban globalisasi dan masyarakat dinegara berkembang tidak selalu menjadi aktor pasif yang tidak memanfaatkan globalisasi. Masyarakat lokal juga mendapat keuntungan dari globalisasi walau pun tidak sebesar keuntungan masyarakat dinegara maju. Masyarakat lokal juga memanfaatkan proses sosial globalisasi sebagai sebuah kesempatan. Sehingga masyarakat lokal sebenarnya adalah aktor aktif dalam globalisasi. Globalisasi terus berlangsung justru karena adanya peran aktif masyarakat di negara berkembang. Masyarakat di negara berkembang memiliki kepentingan dalam globalisasi begitu juga masyarakat negara maju. Kepentingan tersebut bertemu dalam friksi dan bersama-sama saling mendukung proyek globalisasi.

\section{KESIMPULAN}

Teori sosial yang membahas globalisasi tidaklah sedikit, namun dalam tulisan ini memilih empat teori sosial. Masing-masing teori sosial memiliki kekhasannya sendiri, serta masing-masing memiliki basis yang berbeda dalam melihat fenomena yang sama yaitu globalisasi. Tulisan ini menjadi pijakan teoritis untuk research berkenaan dengan fenomena globalisasi di Indonesia. Sehingga arah dan tujuan tulisan ini sebenarnya adalah menemukan teoritis yang tepat untuk penelitian globalisasi pada ranah lokal di Indonesia. Perdebatan berupa kritik-kritik yang tersaji dalam tulisan ini berada dalam lingkup kepentingan untuk menemukan basis teoritis yang tepat dalam melihat fenomena globalisasi pada ranah lokal, yaitu melihat proses sosial berupa keterhubungan lokal yang satu dengan lokal yang lain sehingga membentuk jaringan atau koneksi global. 
Temuan menarik dari tulisan ini menurut saya adalah :

Pertama, globalisasi adalah proses keterhubungan, sehingga fokusnya adalah pada koneksi antar lokal satu dengan lokal lain. Karena itulah maka globalisasi melibatkan peran aktif berbagai pihak yang merupakan aktor-aktor dari globalisasi. Pihak-pihak tersebut bukan hanya pihak dari negara maju tetapi juga pihak dari negara berkembang.

Kedua, kepentingan global merasuk menjadi kepentingan lokal dalam sebuah pertemuan antar kepentingan. Sehingga paksaan global dalam tataran tertentu hampir tidak terlihat nyata dikarenakan adanya kepentingankepentingan berbagai pihak dalam proyek globalisasi tersebut.

Ketiga, globalisasi jangan dipandang sebagai sesuatu hal yang datang dan menemui lokal. Tetapi globalisasi adalah proses sosial yang terjadi dalam berbagai ranah dan landskape. Globalisasi adalah pertemuan-pertemuan antar kepentingan, bukan kepentingan satu pihak menemui kepentingan pihak lain, tetapi proses bertemunya berbagai kepentingan antar berbagai pihak.

Keempat, proyek globalisasi mampu terus bertahan di berbagai jenis lokal dikarenakan kapitalisme. Paham kapitalisme yang membawa pada proses komodifikasi membuat globalisasi terus berjalan. Kapitalisme-lah yang membuat proyek globalisasi berhasil. Kapitalisme bukan sekedar membuat segala sesuatu disegala tempat sama, universal dan homogen seperti yang selama ini dipahami. Kapitalisme juga bersifat partikular.

\section{Daftar Pustaka}

Giddens, Anthony. 2005. KonsekuensiKonsekuensi Modernitas. Yogyakarta : Kreasi Wacana.

George, Ritzer. 2006. The Globalization of Nothing, Mengkonsumsi Kehampaan di Era Globalisasi.
Yogyakarta : Universitas Atma Jaya.

Elias, N., 1997. Towards a Theory of Social Processes: a Translation. British Journal of Sociology, 48, 355-383.

Petras, James. 1999. Globalization: A Critical Analysis. Journal Contemporary Asia. Vol. 29, No. 1.

Rossi, Ino (ed.). 2007. Frontiers of Globalization Research: Theoritical and Methodological Approaches. New York : Springer Science.

Urry, John. 2005. Theory, Culture \& Society : The Complexities of the Global. SAGE Publications.

Tsing, Anna L. 2005. Friction: An Ethnography of Global Connection. Princeton University Press. Princeton 